\title{
The Main Measures Adopted by Romania between 2000-2007 to achieve the Strategic Objectives (Accession to the EU and NATO)
}

\begin{abstract}
Marius Trăistaru ${ }^{1}$
Abstract

This study aims to reveal to what extent the strategic development objectives of Romania (accession to the EU and NATO) bave determined changes in the security policy of Romania between 2000 and 2007.The paper will demonstrate how the security measures adopted by Romania (including in the fight against terrorism) have influenced the economic development of the country. There are numerous debates in the literature that discuss the links between economic development and security (political, economic or military). This study adds to the literature an empirical analysis of a country considered not under a direct threat to security in the region.The research follows a descriptive analysis of the measures in the legislative, institutional and operational areas taken by the Romanian government in the period 2000-2007 in order to reach the start-up objectives (of accession to the EU and NATO). The paper intends to show that these measures taken by Romania did not represent only military and security objectives, but they constituted a platform for the economic development and had economic consequences.
\end{abstract}

Keywords: Romania, terrorism, NATO, European Union, economic development.

JEL Classification: F0, N4, O1

DOI: $10.24818 / \mathrm{REJ} / 2021 / 80 / 06$

\section{Introduction}

In the process of evaluating the security, the conditions for the occurrence and development of multiple threats must be taken into account. One of the premises of this analysis is given by the social, economic and political conditions existing in Romania and in some states in its immediate vicinity characterized by instability, which denotes the need for continuous monitoring of the signals coming from this geopolitical area.

Among the security threats, terrorism has become one of the most discussed issues. Terrorism is the premeditated use or threat to use violence by individuals or subnational groups to obtain a political or social objective through the

${ }^{1}$ Bucharest University of Economic Studies, Romania, marius_traistaru@yahoo.com

Year XXIV no. 80

June 2021 
intimidation of a large audience beyond that of the immediate noncombatant victims (Walter, 2012). Since 2000, articles dealing with terrorist threats have been increasing in number, especially in the context of an openness to a global era and an increasingly interconnected economy.

\section{Review of the scientific literature}

The game-theoretic literature on counterterrorism draws some fascinating strategic contrasts between defensive and proactive countermeasures. In this transnational terrorism scenario, each at-risk country is inclined to work at crosspurposes by engaging in a defensive race in the hopes of transferring the terrorist attacks to other targeted countries (Sandler et al, 1988).

But, in a globalized world the role of new technologies exponentially increases with the benefits, but also with the unwanted consequences/reactions: "The sensational improvement that technology has experienced in the twentieth century, as well as the revolution in the field of communications, besides the multitude of beneficial effects it has had - o, it has also contributed to enhancing the communication and coordination capabilities of terrorists" (National strategy for preventing and combating terrorism", Romanian Intelligence Service-SRI). USA during Bush administration is trying to persuade itself and everyone else that the 'global war on terrorism' (GWoT) will, like the Cold War, be a 'long war' requiring sustained mobilization against an implacable foe. By looking at the surrounding events and contexts that could support or undermine the elevation of the GWoT to the status of the new Cold War, the author argues that it is not all that likely. Many factors could undermine it, not least that most of the strategies on off er corrode the liberal values that they are supposed to defend (Buzan, 2006).

However, the end of the Cold War, a major structural break in the international system, coincided with a change in the causal dynamics between terrorism and growth, instead of expecting a time-constant relationship between the two.At the same time, this period saw the resurgence of nationalist terrorism (e.g., in former Yugoslavia) and the rise of religiously motivated (Islamist) terrorism in, e.g., Egypt and Algeria (Shughart, 2006). That is, the end of the Cold War was associated with an ideological shift in terrorism. Related to this shift was a change in terrorism geographical distribution (Enders et al, 2006). For instance, many Western and Latin American countries witnessed a decline in (left-wing) terrorist activity after the end of the Cold War, whereas many Middle Eastern and African countries saw an increase in Islamist and nationalist-separatist terrorism (Meierrieks et al, 2013).

Year XXIV no. 80

June 2021 
As for Romania, the membership of the North Atlantic Alliance, as well as the complex process of integration in the EU (a security space based on common values, interests and objectives, on the principles and norms of democracy, the rule of law and the market economy), offered our country favorable conditions for accelerated economic and social development. From that moment, Romania received an enormous chance in achieving the national desire, respectively that of national prosperity.

\section{Research methodology}

In order to analyze the way in which the terrorist phenomenon evolved in the period 2000-2007 in Romania, in the socio-political context of that period, we used the method of descriptive analysis. Thus, the analysis of statistical data resulting from the study of the literature was made from the perspective of the fact that the terrorist phenomenon is one of the main threats related to national security.

In this sense, in this chapter I considered it necessary to make a brief review of the main landmarks of Romania's pre-accession route (to NATO and the EU).

Thus, in 2004 was officially completed the process of accession of our country to NATO, also celebrating 10 years of Romania's participation in the Partnership for Peace/PfP, which was launched on January 26, 1994. Romania became the first state in the world to sign the PfP Framework Document. Also, in the same year, the first high-level NATO meeting was held in Istanbul, in which Romania participated as a full member.

With regard to the EU, after the accession treaty was signed on April 25, 2005, Romania became an accession state, obtaining the status of active observer at the level of all EU institutions. At the same time, it was insured the presence of Romanian representatives at the level of European bodies and working groups. The status of active observer allowed our country to express its point of view, without voting rights, in the decision-making process at EU level. Thus, Romania could influence the decisions and, in parallel, promote their national interests. January 1, 2007 will remain historic for Romania, being the day of entry into the European Union. Romania has moved from the active observer status to the member with full rights.

Year XXIV no. 80

June 2021 
Along with joining NATO, on 29.03.2004, Romania's integration into the European Union is the most important national political achievement since the December 1, 1918 Union national, respectively that of national prosperity.

Actions to prevent and combat terrorism in Romania were regulated, in the first instance, mainly by Law 535/2004. In Article 1, it defines terrorism through two main elements: actions aimed at having a strong negative impact on the population and pursuing a political purpose. Article 3 introduces the notion of "transnational" terrorism, which involves their deployment or planning in the territory of another state. However, in the reference period, the Government, the Presidency, the Romanian Intelligence Service/SRI, as well as international experts stated that the risks of terrorist attacks in Romania are low, without making any distinction between transnational and "internal" threats. Despite the fact that the institutions of the Romanian state with attributions in national security have permanently created the impression that the situation related to this plan has always been under control, the questions regarding the capacity of the state to respond to threats to a much greater extent by appropriate means, with reasonable costs and no effects, persist. Even if to prevent the occurrence of such actions it was necessary to adopt restrictive measures that were enjoyed and significant public support, this did not guarantee protection against terrorist attacks. Eloquent in this regard is the opinion of Tiberiu Dragu (2011), who shows, in a study ('Field of Political Economy"), that "antiterrorism agencies tend to prefer reductions in restrictions. accessing the personal data of citizens from an institutional logic, but often without reducing the likelihood of a terrorist attack". On the contrary, Dragu's analysis shows that there are situations in which a decrease in confidentiality in the data circuit may even lead to a decrease in national security by diminishing the incentives of the anti-terrorism agencies to concentrate their efforts to detect possible plots.

\section{Results and discusision}

Following the research carried out by conducting a descriptive analysis of the measures in the legislative, institutional and operational fields taken by the Romanian government in the period 2000-2007 in order to achieve the starting objectives (EU and NATO accession). The measures implemented by the Romanian state at that time were analyzed according to the measures taken by international organisms to combat terrorism.

Year XXIV no. 80

June 2021 
In this regard, I will list some of the counter-terrorism measures implemented during that period, domestically and internationally, and I will analyze their effectiveness.

Human losses caused by terrorism are tragic and it is important to reduce them as much as possible. In democratic societies, the public opinion supports after each major attack the adoption of energetic measures aimed at reducing the chances of their repetition. However, there is a risk that the measures will not be effective, as well as the risk that they will be accompanied by negative side effects that far outweigh the benefits. Thus, the costs of many efforts to combat terrorism are extremely high when compared to the number of lives saved. Between 2001 and 2007 , direct costs for increasing security globally were estimated at $\$ 70$ billion (Jiglău, 2015). The magnitude of these costs may seem paradoxical, given that the number of victims of transnational terrorism after 2001 averaged 583 per year globally, a very small number compared to other categories of deaths that may be limited, such as HIV/AIDS, malaria, air pollution or car accidents.

A government ought to weigh the cost of giving in to terrorist demands (i.e., objectivs not enforceable in the political process) against the present and anticipated costs of a prolonged terrorist campaign that result from continued resistance by the government (Sandler et al, 2008). Then, economic destabilization ought to be a central goal of terrorists as it improves their bargaining position by inflicting costs upon the government. Country-specific factors are anticipated to matter to terrorist $\mathrm{s}$ calculus in that they affect their cost-benefit considerations, given that terrorists (as rational actors) consider the costs, benefits, and opportunity costs associated with violence to choose its optimal level.

On the one hand the attacks in places with public resonance, sometimes filmed and even played live, lead to public pressures greater than the deaths that occur in less visible contexts, and the political costs of reactions perceived by citizens they are just as energetic as they are. In conclusion, the economic costs of terrorism in rich countries are low, relative to the economic costs of combating terrorism; both are likely high in poor countries (Keefer et al, 2008).

Because of terrorists presumed rationality, the opportunity costs of terror also matter. Intuitively, lowopportunity costs of violence that is, few prospects of economic activity - lead to elevated terrorist activity, whereas high opportunity costs result in the opposite (Gries et al, 2009).

Despite the efficiency problems, the western states' reactions to the terrorist attacks have mostly been in the category of "traditional" measures, most often 
being substantial in terms of costs and institutional design. Thus, following the American attacks of 2001, the first reactions came from the United Kingdom and France, the latter assuming an increase of over 3 billion euros in the defense budget, of which a significant part returned to the gendarmerie to maintain order and fight against internal terrorism. The presence of France in the management of the international security environment has become significant in areas considered as terrorism providers.

The Madrid (2004) and London (2005) attacks led to additional security measures, including raising the defense budget to $2.6 \%$ of GDP (committing an additional $€$ 10 billion) and transposing the European Directive on the retention of personal data, a rule declared unconstitutional for the violation of individual freedoms by several Member States, including Germany, Austria, the Czech Republic, Bulgaria and Romania on several occasions (the rejection of the law concerns only the initial forms of laws called Big Brother), as well as the European Court of Justice.

The terrorist attacks carried out in the European countries, between 2000 and 2007, targeted not only material damage, but also the destabilization of political systems and financial markets. The effects of possible attacks in Romania could have been substantial due to the problems of functioning of democracy, reflected in a low level of trust in the institutions, and the measures taken should have given priority to this type of vulnerability.

Analyzes of transnational attacks from 2000-2007 have shown that they are more likely when there is a high potential for social destabilization. In these coordinates, to reduce the probability of having attacks and to limit the negative effects, four categories of measures were highlighted:

1. Measures to increase the transparency of institutions with national security responsibilities. In this case, an attempt has been made to attach particular importance to the idea that changes in legislation with implications for national security must take place under high transparency conditions. Thus, it was taken into account that the premises from which the discussions on the control mechanisms on the activity of the secret services should start are to be found in the documents of the international bodies to which Romania aspired to be integrated.

In order to be able to effectively control the activity of the secret services, it was important for the members of the control committees (parliamentary or independent) to have access to secret information, which involved new "challenges". Thus, the access of a large number of politicians to intelligence

Year XXIV no. 80

June 2021 
increased the risk of using this information for political purposes. At the same time, the involvement of all the political forces in the Parliament and the increasing role of the opposition in the control activity, as well as the involvement of apolitical experts in the process, reduced the risk of information leakage and misuse of information.

The rethinking of the legal framework regarding national security envisaged the efficiency of the control mechanisms on the secret services, by including in the process some apolitical experts, part of the civil society. They could be included in parliamentary committees or function as an independent body, coordinating with the parliamentary control committees, but also with the Supreme Defense Council of the country, and which could act as a bridge between the secret services and the public, taking over referrals to citizens and forwarding them to decision makers or, where appropriate, to the courts. The selection of these experts fell to joint committees made up of parliamentarians and members of the extended civil society and should have been conducted on a competitive basis, and the expertise, past activity and moral probity of those who could have become members were to be evaluated commission. Moreover, such a commission did not affect the role of Parliament, which remained the main forum for controlling the activity of services, especially through committees.

Last but not least, the problems of ethics and professionalism associated with the educational structures of the army and services, which were publicized during that period, emphasized that reforms in higher education were needed from the perspective of increasing the quality of human resources in national security institutions.

2. Informing the population about the measures already provided by the legislative framework, as well as identifying ways to ensure a better implementation of the legislation regarding cooperation between institutions.

The existing legislative framework provided some tools aimed at preventing threats through cooperation and involvement of the population, but these are too little publicized.

Since then the principle of cooperation between institutions has been present in the legislative framework.

Article 6 of Law 535/2004 establishes that the SRI manages the Anti-Terrorism Operational Coordination Center, but mentions all public institutions and 
authorities, 21 in total, which participate in the National System for the Prevention and Combating of Terrorism.

On the other hand, there are similar formal protocols for collaboration between institutions and for other threats to the safety of citizens, but events such as the fire in the Collective, but also the interventions in case of calamities such as floods or blockages caused by snowfall illustrate the malfunctions that appear in their implementation.

3. Measures to improve the mechanisms of political representation of citizens in order to reduce the chances of radicalization of certain categories of citizens and to increase the degree of confidence in political institutions with attributions regarding national security.

From the perspective of political stability, the encouragement of political participation in Romania and the separation of powers in the state, both within the reference period and at present, the priority was/is represented by the implementation of some constitutional and legislative reform measures, meant to increase the level of trust of citizens in political institutions and stimulate their involvement. Political instability, lack of social cohesion, lack of confidence in state institutions or even loss of state legitimacy in relation to society or groups within it are among the possible causes that favor the emergence of "internal" terrorism or vulnerabilities to transnational terrorism.

Another problem, not yet solved so far, is the revision of the Constitution, which could be a good opportunity for a sharp debate on the rights of minorities and their state, especially the Hungarian minority, whose demands were most often considered exaggerated after 1990.

4. Romania is committed to being part of the international effort to remedy the primary sources of terrorism. Rapid exchange of information between countries on suspicious persons and cooperation in identifying terrorist financing sources and eliminating them are the most effective means of limiting large-scale attacks.

A turning point at the international level constituted 9/11 (the terrorist attacks of September 11, 2001), which inoculated in the public opinion a series of "threats" ("generalized insecurity", "endless threat" or "how to" distinguish the friend from the enemy? "), which have been doubled the major challenges of the" new world order "(" how are theaters of war delimited? "or" how do you assess the duration of hostilities?") because when the enemy is the terrorist, it seems it is quite impossible for it to be located or to anticipate its strategy of action.

Year XXIV no. 80

June 2021 
The significant effect of this international "tsunami" was the conclusion of the era of territoriality (symbolic end inscribed in the collective memory) because the notions like force/weakness or threat/security became "extraterritorial issues that exceed the application of territorial solutions".

On these coordinates, the internationalization of the terrorist phenomenon connected with the existence of "sponsor states" or logistical bases of terrorist organizations on the territory of "failed states" constituted asymmetrical threats to international security, which made intelligence as the main weapon in combating terrorist activity.

Measurement issues round out the expectation thatdiscrimination in particular is a key predictor of domesticterrorism in countries and can help to explain the linkbetween poverty and terrorism (James A. Piazza, 2011).

However, in our country there were no indigenous terrorist groups, the main threats of a terrorist nature against the national security of Romania deriving from the external evolutions that could influence the dynamics of foreign organizations, internationally classified as terrorists.

But, considering that, between 2000-2007, the authorities in Bucharest acted as a priority in order to achieve the accession objectives, Romania was in the attention of terrorist organizations for possible attacks from at least three perspectives: as a future member state of the North-Atlantic Alliance and The European Union (so as part of the Western civilization against which part of the terrorist attacks and especially those of the Islamic fundamentalist groups are targeted), as a country in the vicinity of the Muslim front (in the Black Sea and Balkan area) and as an active participant in the World War against terrorism.

Another factor that influenced the dynamics of threats to national security was the involvement of terrorist organizations with representation on the national territory in activities of illegal migration to the West of people from the Middle East, Asia or Africa, some of them known to be involved in terrorist activities in the areas of origin.

Also, the money transfers in order to support the terrorist activities through illegal methods represented (and constitute at present) a threat to the national security of Romania, the terrorist organizations aiming and obtaining funds by carrying out activities, licit (trade, import- export) or illicit (drug, arms trafficking, illegal migration, smuggling, etc.) within our country.

Year XXIV no. 80

June 2021 
In this regard, for the interval under review, I consider that the measures taken by the Romanian special services (in particular, SRI) on the following coordinates, aspects identified by Cristian Barna (2013) should be mentioned:

- preventive measures to eliminate the risks and threats against Romania, generated by the import of terrorism due to the Israeli-Palestinian conflict: in November 2006, the Lebanese citizen Mahmoud Ahmad Mahmoud was declared undesirable, for a period of 15 years, for financial, logistical and operational support activities in favor of Hezbollah, as well as for the recruitment of some members and supporters of the mentioned group in order to operationalize of an organized crime group (arms trafficking, currency, drugs, etc.).

- preventive measures to eliminate the risks and threats to Romania, generated by the import of terrorism from Islamic fundamentalist sources: the expulsion, in 2005, of five Arab citizens suspected of involvement in the recruitment activities of followers, in order to set up an Islamic fundamentalist cell of AlQaeda inspiration in Iasi. The cell's leader was Saudi citizen Musaab Ahmed Mohamed Mujalli, who is said to have undergone training in Al-Qaeda camps in Afghanistan. Musaab Ahmed Mohamed Mujalli possessed propaganda materials that promoted Jihad, as well as a guide to building and using an explosive device, being concerned with establishing links with Al-Qaedaaffiliated structures and planning terrorist attacks in Romania. A similar case is that of the Yemeni citizen Mohtar Hashedi, detained in July 2006, in Constanta, being subsequently expelled for actions that could endanger the national security of Romania, by recruiting some Muslim citizens for the purpose of establishing a terrorist cell.

- preventive measures to eliminate the risks and threats against Romania, generated by the import of terrorism due to Kurdish separatism in Turkey: on September 23, 2003, Ozkizil Cemal, a member of the Romanian organization of the terrorist organization Congress of the People's Congress of Kurdistan (Kongra Gel) formerly the Kurdistan Workers' Party (PKK) - was declared undesirable for 10 years, the one involved the territory of our country in the collection of funds (including by violent means or related to organized crime), propaganda, illegal migration in favor of nationals, members or supporters of the mentioned group.

Despite the fact that the budgets allocated to the Ministry of National Defense and the special intelligence services increased every year (with percentages between 8 and 22\%), in Romania no additional security measures were announced for the citizens to consider. However, the amounts directed towards the national security field constituted an economic development platform for an important segment of the country's population.

Year XXIV no. 80

June 2021 


\section{Conclusions}

In the period 2000-2007, Romania acted in the direction of respecting the international commitments in the spirit of loyalty and prudence. At the same time, it sought to find a balance between commitments and national sovereignty - the sovereignty of setting its priorities and acting according to internal and geostrategic needs. Also, the Romanian authorities understood that transparency and wide consultation is important in order to find the best ways to address threats and to implement international measures.

On the other hand, Romania has not been able to more clearly outline its ambitions as a regional actor, given the steps taken to rethink the mode of action against the terrorist phenomenon at international level.

\section{References}

Barna C., 2013, About intelligence and terrorism in Romania, Intelligence Magazine.

Buzan B., 2006, Will the 'global war on terrorism' be the new Cold War?

Dragu T., 2011, Field of Political Economy, American Political Science Association.

Enders W., Sandler T., 2006, Distribution of transnational terrorism among countries by income class and geography after $9 / 11$.

Enders W., Sandler T., 2012, The Political Economy of Terrorism.

Gries Th., Krieger T., Meierrieks D. (2009), Causal Linkages Between Domestic Terrorism and Economic Growth.

Jiglău G., 2015, How can Romania prevent terrorist threats?, www.contributors.ro.

Keefer Ph., Loayza N., 2008, Terrorism, Economic Development and Political Openness.

Piazza J.A., 2011, Poverty, minority economic discrimination and domestic terrorism.

Meierrieks D., Gries Th., 2013, Causality between Terrorism and Economic Growth.

National strategy for preventing and combating terrorism, Romanian Intelligence Service-SRI, 2002.

Sandler T., Lapan, H.E., 1988, The calculus of dissent: an analysis of terrorists' choice of targets.

Sandler T., Enders W., 2008, Economic consequences of terrorism in developed and developing countries.

Shughart W.F., 2006, An Analytical History of Terrorism, 1945-2000.

Year XXIV no. 80

June 2021 